\title{
SPECTROPHOTOMETRIC ESTIMATION OF METFORMIN IN HUMAN PLASMA
}

\author{
Dr Bhavya Sri*1, Amina Fatima ${ }^{2}$, Dr D.Rambabu ${ }^{3}$ \\ ${ }^{1,2}$ Department of Pharmaceutical Analysis, RBVRR Women's College of Pharmacy, Barkatpura, Hyderabad, \\ India \\ ${ }^{3}$ Gland Pharma. Pvt. Ltd.
}

Article Info: Received 10 May 2019; Accepted 02 June. 2019

DOI: https://doi.org/10.32553/jbpr.v8i3.609

Address for Correspondence: Dr Bhavya Sri, Department of Pharmaceutical Analysis, RBVRR Women's College of Pharmacy, Barkatpura, Hyderabad, India

Conflict of interest statement: No conflict of interest

\section{ABSTRACT:}

To develop a simple, selective and sensitive spectrophotometric method and validated for the determination of metformin in human plasma. The method was applied for the determination of metformin from pharmaceutical preparations and plasma samples and after spiking with metformin. The results were checked by standard addition method. A number of pharmaceutical additives and plasma matrix did not affect the determination of metformin. The proposed method was found to be accurate and precise for routine estimation of metformin hydrochloride in human plasma.

Keywords: Metformin, spectrophotometric, standard addition, plasma, pharmaceutical preparation

\section{INTRODUCTION}

Metformin $\mathrm{HCl}$ (1,1-dimethylbiguanide $\mathrm{HCl})$, first developed in 1957, is one of the most commonly used oral anti-hyperglycemic agents for the treatment of Type II diabetes mellitus. It is currently recommended as first-line therapy in overweight or obese patients with this condition (1). However high concentration of metformin in plasma has been associated with an increase in the incidences of lactic acidosis, particularly in patient in acute renal failures. The methods for the quantitation of metformin from pharmaceutical preparations and biological fluids include spectrophotometry $[5,6]$, gas chromatography [79], high performance liquid chromatographytendom mass-spectrometry (HPLCMS-MS) [10], reversed phase $\operatorname{HPLC}[11,12]$, ion pair $\operatorname{HPLC}[13$, 14]. The spectrophotometric methods are simple and required sensitivity and selectivity could be achieved. Regarding sample preparation from biological fluids, extraction and clean-up of the sample is a critical first step in bioanalysis and requires high selectivity. Organic liquid-liquid extraction is a simple and effective method of affording sample cleanup for most analytes.
Unfortunately, in the case of metformin, this approach is challenging because of the drug's polar characteristics. Herein, a method that successfully employs the liquid-liquid extraction of metformin and capable of measuring metformin in small volumes with high sensitivity.

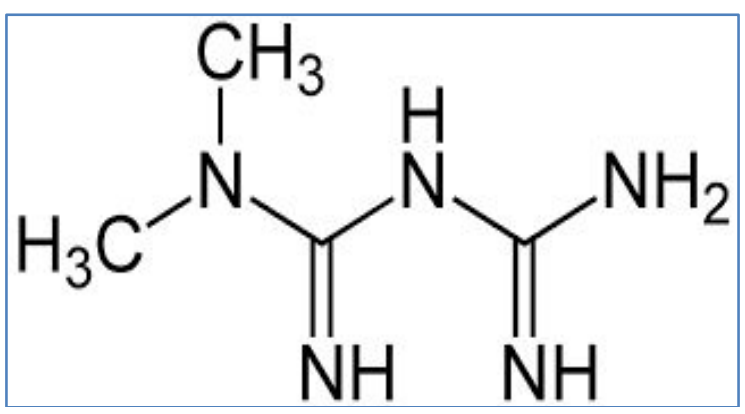

Figure 1: Chemical structure of metformin HCL

MATERIAL AND METHODS:

\section{Chemicals and reagents:}

metformin $\mathrm{HCL}$ were obtained as gift sample from pharmaceutical Laboratories Ltd. Perchloric acid, Acetonitrile and water used were of analytical grade (FINAR limited, hyderabad, India).. All other chemicals and reagents used were analytical grade unless otherwise indicated. 
Vikas R. Mathad et al., Journal of Biomedical and Pharmaceutical Research

\section{Instrumentation}

The proposed work was carried out on a ELICO UVvisible spectrophotometer (model SL 210), which possesses a silicon photodiode detector with a1 $\mathrm{cm}$ quartz matched cell. All weighing was done on electronic balance (Wensar HPB 220).

\section{Selection of Solvents:}

The water solubility of metformin $\mathrm{HCL}$ was found to be $1.38 \mathrm{mg} / \mathrm{ml}$, log $\mathrm{p}$ value -1.8 and $\mathrm{pKa}$ (strongly basic) 12.33 On the basis of solubility study perchloric acid and Acetonitrile was selected for extraction.

\section{Preparation of Standard Stock Solution of Metformin:}

\section{Metformin Stock Solution}

An accurately weighed quantity of Metformin (100 $\mathrm{mg}$ ) was taken in $100 \mathrm{~mL}$ volumetric flask and dissolved in water $(50-\mathrm{mL})$ with the help of ultrasonication for about $5 \mathrm{~min}$. Then the volume was made up to the mark using methanol to get metformin standard stock solution (1 $\mathrm{mg} / \mathrm{mL}$ ).

\section{Metformin Working Standard Solution}

Metformin standard stock solution $10 \mathrm{mLwas}$ diluted to $100 \mathrm{~mL}$ using to get working standard solution $100 \mu \mathrm{g} / \mathrm{mL}$.

\section{Preparation of biosample:}

$500 \mu \mathrm{L}$ volume of plasma or erythrocyte from individuals not recieving metformin was transferred to $1.5 \mathrm{~mL}$ polyproplylene microextraction tube. Extraction was performed by adding $50 \mu \mathrm{L}$ of metformin working standard to the tube and shaking for 60 seconds, followed by centrifugation at $10000 \mathrm{~g}$ for 10 minutes, the whole organic layer was separated into another tube, then $200 \mu \mathrm{L}$ of perchloric acid $10 \%$ was added, the mixture was vortexed and centrifuged at $10000 \mathrm{~g}$ for 5 minutes. From the organic layer $0.1 \mathrm{~mL}$ of extract was transferred to $10 \mathrm{~mL}$ volumetric flask and volume was made upto $10 \mathrm{~mL}$ with distilled water. The absorbance of sample is determined using water as blank solution at $233 \mathrm{~nm}$.

\section{Determination of $\lambda$ Max of Metformin HCL:}

An appropriate aliquot portion of metformin $(1 \mathrm{~mL})$ was transferred to $10 \mathrm{~mL}$ volumetric flask, the volume was made up to the mark using distilled water to obtain $10 \mathrm{ppm}$ solution of Metformin. Drug solution were scanned between $200 \mathrm{~nm}$ to $400 \mathrm{~nm}$. Metformin shows $\lambda$ max at $233 \mathrm{~nm}$.

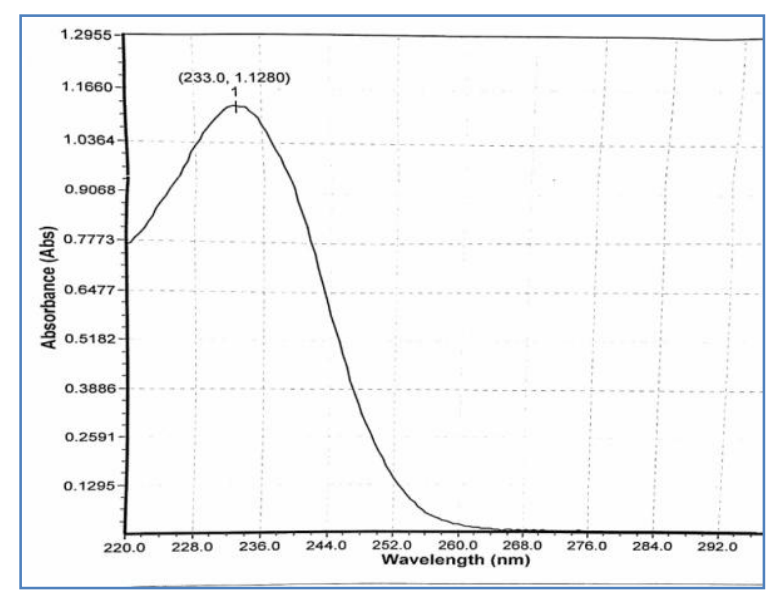

Figure 2: spectra of metformin HCL

\section{Linearity Studies:}

An accurately measured aliquot portion of working standard solution of was transferred to seven separate $10 \mathrm{~mL}$ volumetric flasks. The volume was made up to the mark using $77 \%$ ss v/v methanol to obtain concentrations $(10-160 \mu \mathrm{g} / \mathrm{mL})$. Absorbance of these solutions was measured at $274 \mathrm{~nm}$, (Table1) Calibration curve was plotted, Absorbance Vs Concentration as shown in (Fig. 1).

Table 1: Regression and Optical characteristics of metformin

\begin{tabular}{|l|l|}
\hline Parameters & Values \\
\hline Beer's law limit $(\mu \mathrm{g} / \mathrm{mL})$ & $20-100 \mu \mathrm{g} / \mathrm{ml}$ \\
\hline Correlation Coefficient $(\mathbf{r})$ & 0.997 \\
\hline Regression equation & 0.203 \\
\hline Slope & 0.230 \\
\hline Intercept &
\end{tabular}

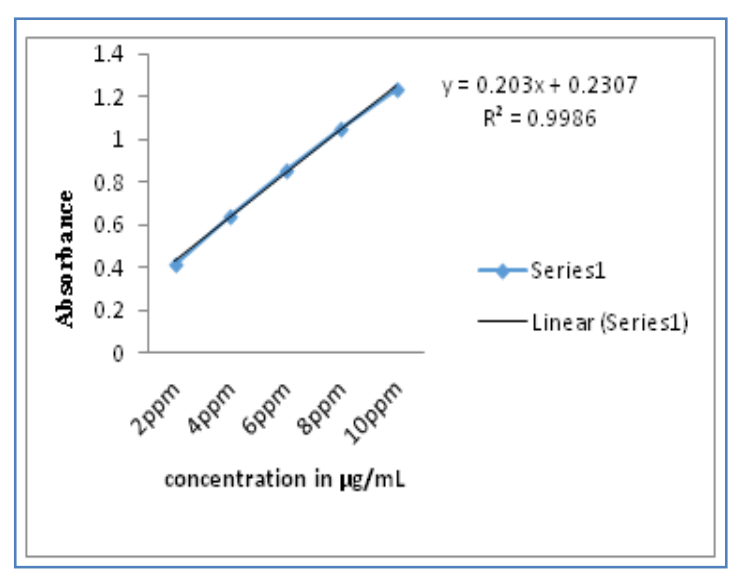

Figure 1: calibration plot of metforminHCL 
Vikas R. Mathad et al., Journal of Biomedical and Pharmaceutical Research

\section{Accuracy [Recovery Study}

Accuracy of proposed method was ascertained on the basis of recovery study performed by standard addition method. A known amount of standard drug solutions were added to the sample to make final concentrations in the range of $80 \%, 100 \%$ and $120 \%$ and re-analyzed it by the proposed method. The absorbance recorded and the $\%$ recoveries were calculated using formula. \% Recovery $=[A-B /$ C] $\times 100$

Where,

$A=$ Total amount of drug estimated

$B=$ Amount of drug found on preanalysed basis

$\mathrm{C}=$ Amount of Pure drug added

The results are reported in (Table 41).

Table 2: Recovery Study.

\begin{tabular}{|l|l|}
\hline Drug in solution $\mu \mathrm{g} / \mathrm{ml}$ & \%recovery \pm S.D \\
\hline 40.10 & $100.04 \pm 0.021$ \\
\hline 60.02 & $99.56 \pm 0.056$ \\
\hline 80.05 & $99.59 \pm 0.032$ \\
\hline
\end{tabular}

S.D. =Standard Deviation

\section{Robustness}

The robustness was carried out to evaluate the influence of a small but deliberate variation in the spectrometric condition for determination of Metformin $\mathrm{HCl}$ in biosample. The Robustness data for variations in wavelength of detections $( \pm 5 \mathrm{~nm})$ and the absorbance and its analytical performance parameters of Metformin $\mathrm{HCl}$ were shown in Table

Table 3: Robustness Study.

\begin{tabular}{|l|l|l|}
\hline \multirow{2}{*}{$\begin{array}{l}\text { Wavelength in } \\
n\end{array}$} & \multicolumn{2}{|l|}{ metformin $20 \mu \mathrm{g} / \mathrm{mL}$} \\
\cline { 2 - 3 } & $\begin{array}{l}\text { Absorbance found } \\
\text { in } \mu \mathrm{g} / \mathrm{mL} \\
\text { Mean S.D. (n=3) }\end{array}$ & \% R.S.D. \\
\hline 238 & 0.42020 .001 & 0.0010 \\
\hline 228 & $0.4109 \pm 0.019$ & 0.0069 \\
\hline
\end{tabular}

ACKNOWLEDGEMENT:

The authors are grateful to the authorities of RBVRR Women's College of Pharmacy, hyderabad for the facilities.

\section{REFERENCES:}

1. Scheen AJ. Clinical pharmacokinetics of metformin. Clin Pharmacokinet 1996;30:359-

2. Simple hplc-uv method for determination of metformin in human plasma and erythrocytes application to therapeutic drug monitoring , International Journal of Pharmacy and Pharmaceutical Sciences 2015-ISSN-0975-1491

3. Willard $\mathrm{HH}$ and Merritt II. Instrumental method analysis. New Delhi: CBS Publication and Distribution; 2001

4. Sethuraman $S$, Adhakrishnan $K$, Venkateswarlu V, Sravani M, Ramathulasi G, Bhanuteja S. Estimation And Degradation Monitoring Of Cefadroxil In Pharmaceutical Dosage Form By Using UV-Spectroscopy. Asian Journal of Research in Biological and Pharmaceutical Sciences. 2014; 2(1):27-33. 17.

5. Tache F, Albu M. Specificity of an Analytical HPLC Assay Method of Metformin Hydrochloride. Revue Roumaine De Chimie. 2017;52(6):603-609.

6. Vesterqvist $O$, Nabbie $F$, Swanson B. Determination of metformin in plasma by high-performance liquid chromatography after ultrafiltration. J Chromatogr B: Biomed Sci Appl 1998;716:299-304.

7. Karkhanis VV, Anand Kumar DC, Patel P. Development and Validation of UV Spectrophotometric Method for Estimation of Glipizide in Bulk and Pharmaceutical Dosage Forms. Int J Pharmaceutical Science and Res. 2013;4(5):1865-67

8. Amini $H$, Ahmadiani A, Gazerani P. Determination of metformin in human plasma by high-performance liquid chromatography. J Chromatogr B: Anal Technol Biomed Life Sci 2005;824:319-22. 21

9. Cheng $\mathrm{CL}$, Chou $\mathrm{CH}$. Determination of metformin in human plasma by highperformance liquid chromatography with spectrophotometric detection. J Chromatogr B: Biomed Sci Appl 2001;762:51-8. 19.

10. Chatwal GR and Sham KA. Instrumental method of chemical analysis. 5th ed. Mumbai: Himalaya Publishing House; 2002;626-636. 20.

11. Beckett $\mathrm{AH}$ and Stenlake JB. The Practical Pharmaceutical Chemistry. Part II. New Delhi: CBS Publishers and Distributors; 1997. 21. 
12. Lloyd RS, Joseph JK, Joseph LG. Practical HPLC Method Development. 2nd ed.York: Wiley Wiley-Interscience publication; 1997.

13. Narasimha Rao D, Chandana M. Method Development and Validation of RP-HPLC Method for Simultaneous Analysis of ThreeComponent Tablet Formulation containing Metformin Hydrochloride, Pioglitazone Hydrochloride, and Glibenclamide. Int J Pharm Tech Research. 2012;4(3):948-956

14. Neelima K, Prasad YR. Analytical method development and validation of metformin, voglibose, glimepiride in bulk and combined tablet dosage. Pharmaceutical Methods. 2014;5(1):27-33.

15. Zarghi A, Foroutan SM, Shafaati A, Khoddam A. Rapid determination of metformin in human plasma using ion-pair HPLC. J Pharm Biomed Anal 2003; 31: 197-200 and Bioanalytical Chemistry. 2011; 1(3): 70-76.

16. Canadian Diabetes Association 2008 Clinical Practice Guidelines for the Prevention and Management of Diabetes in Canada. Can J Diab 2008; 32: S1-S201.
17. Porta V, Schramm SG, Kano EK, Koono EE, Armando YP, Fukuda K, Serra CH. HPLC-UV determination of metformin in human plasma for application in pharmacokinetics and bioequivalence studies. J Pharm Biomed Anal 2008; 46: 143-147

18. Dey S, Kalyani K, Samyuktha B, Sahoo SK, Mohapatra S, Murthy PN, Kumar D. Development And Validation Of A UV-Vis Spectrophotometric Method For The Estimation And Degradation Monitoring of Metformin In Bulk And Pharmaceutical Dosage Forms. Int J Chem Res. 2010;1(1):29-34

19. Deveaux M, Dallet $P$, Quintin C, Nisse $P$, Gosset D. Ultra-short determination of metformin in plasma by hydrophilic interaction liquid chromatography. Ann Toxicol Anal 2002;14:125-8.Lalau JD, Lacroix C, Couragon P, Decagney B, Rigaud JP, Bleichner $G$, et al. Role of metformin accumulation in metformin-associated lactic acidosis. Diabetes Care 1995;18:779-84 